\title{
Corporate Social Responsibility and Tax Avoidance: Egypt Evidence
}

\author{
Awad E. Ahmed \\ Accounting Department, Faculty of Commerce \\ Sohag University \\ Sohag, Egypt \\ ahmed.bakry@commerce.sohag.edu.eg
}

\begin{abstract}
Purpose - This paper aims to investigate the association between Corporate Social Responsibility (CSR) performance and tax avoidance (TA) across a sample of Egyptian firms.

Design/methodology/ approach - Using the Egyptian Corporate Responsibility Index (S\&P/EGX ESG Index) and extracting accounting data from the annual reports of non-financial companies listed on this index, a data analysis on a sample of 179 firm-year observations for a nine-year period beginning in 2007 was used.

Findings -The empirical results of the multivariate regression indicated that Egyptian companies active in CSR are less likely to engage in TA practices. This evidence is consistent with the notion that paying the fair share of taxes is a part of firm's CSR package.

Practical implications - The findings of the study also have policy implications, by providing a better comprehension of TA practices and CSR that might be in favor of numerous investors, regulators and academics interested in firms' tax behavior. Besides, it also helps tax administrations to identify the conditions under which the risk of aggressive tax practices increases, thus helping to formulate effective tax systems that improve the level of firms' tax liability.

Originality/Value - This study is the one of the first studies that examines the relationship between CSR and TA practices in Egypt. In addition, this article provides an empirical evidence on this relationship from the Egyptian environment that is different from other cultural and institutional environments in which previous studies were conducted.
\end{abstract}

Keywords: Corporate Social Responsibility, Tax Avoidance, Effective Tax Rate.

\section{Introduction}

Tax is related to the interests of the whole society since it represents an important source of funds enriching the national fiscal revenue and supporting domestic infrastructure construction, education, healthcare system, national defense, public transport and law enforcement. Therefore, complying with the underlying spirit of the tax law is important for a firm to gain legitimacy in society and retain good-standing with the tax authority (Ostas, 2004; Rose, 2007) and it can be said that firm's paying its fair share of the tax lawfully collected by governments in whichever country they are operating is one of its obligation towards the society (Christensen and Murphy, 2004).

Despite the importance of taxes in providing a good corporate environment, some firms treat them as a cost that should be minimized. They legally engage in strategic tax practices designed solely to minimize

* This article was submitted in June 2019, and accepted for publishing in August 2019.

(c) Arab Administrative Development Organization- League of Arab States, 2021, pp 301-312،

DOI: 10.21608/aja.2021.205201 
its corporate taxes through transferring a larger share of the overall tax burden onto lower tax jurisdictions, and such practices are often called tax avoidance (TA) practices (Avi-Yonah, 2008).

Management might be encouraged to engage in TA practices to benefit shareholders in the short term because of cash savings that those practices might provide and can be used by managers to generate future shareholder wealth; however, such practices might harm the firm's sustainability and impair the firm's market value. The media continually criticize those practices and consumers' awareness of firm's performance is largely influenced by news about socially irresponsible activities compared to those about socially responsible activities; therefore, such negative publicity may cause reputational harm to firms that engage in TA practices, which in turn may cause financial harm to their shareholders (Lanis and Ricardson, 2012).

TA practices may not harm only firms and their shareholders but also the citizens and governments of nations that serve as tax havens for these practices since governments are left powerless to sustain basic services when earnings are stripped and sent to lower tax jurisdictions. Therefore it can be said that TA behaviors are always widely considered to be irresponsible, immoral, and even unpatriotic by the government institutions and the public, which deviates from the concept of Corporate Social Responsibility (CSR) (Knuutinen, 2013).

According to theories of corporate culture, legitimacy, and shared value (Dowling and Pfeffer, 1975; Kreps 1990; Porter and Kramer, 2006), TA practices are inconsistent with CSR, as those practices are costly to the society and they might be considered by the public and the press as unethical and irresponsible activities. Some empirical studies (Hoi et al., 2013; Landry et al., 2013; Lanis and Ricardson, 2012, 2015) indicated that CSR firms are with higher effective tax rate than other firms. In contrast, it is stated by risk management theory (Fombrun et al., 2000; Moser and Martin, 2012) that TA practices might expose firms to severe risks such as loss of reputation, increased political and media pressure, possible fines and penalties by the tax authority, and consumers' boycotting of corporate products. In such cases, firms might protect the loss of their reputation by managing CSR activities. Borza and Stoian (2011), Davis et al. (2013) and Huseynov and Klamm (2012) empirically support this argument.

Due to the confusion of previous results, it is vital to study this issue in Egyptian environment especially after the issuance of the Income Tax Law No. 91 of 2005 that provide tax advantages and exemptions for firms that engage in CSR activities and those firms might tend to misuse this regulation to reduce or eliminate the tax burden.

The purpose of the current paper is to it investigate whether CSR firms - as determined by the Egyptian Corporate Responsibility Index (SandP/EGX ESG Index) - engage in TA practices. Specifically, it examines whether Egyptian companies engage in CSR activities as social contribution or as a cover for aggressive tax practices.

Based on a sample of 179 firm-year observations from 2007 to 2016, and after controlling for organization-specific characteristics and using the effective tax return (ETR) as a proxy of TA, it is found that the higher the company's ranking in relation to their social responsibility, the higher their ETR.

The remainder of this paper is structured as follows: Section 2 discusses the literature review and hypothesis formulated on the basis of theoretic anticipations. Section 3 discusses the research methodology. The research results are discussed in Section 4. Finally, Section 5 presents the conclusion, and discusses implications of the results, the limitations of this study and suggestions for possible future research.

\section{Literature Review and Hypotheses Development:}

The concept behind corporate social responsibility (CSR) is that firm is a "real world" entity that should consider the concerns of the broader society and meet the expectations of all their stakeholders including employees, shareholders, consumers, communities and governments (Jones, 1995). 
One of the most important social obligations of firms is complying with tax rules since tax is an important tool to provide governments with the necessary funds to provide the necessary public goods and services to all members of society. Despite of the value of tax, many firms consider it as a burden must be reduced or eliminated completely, and hence management began in contracting with advisers and experts in the field of tax to formulate tax strategies that aim to avoid payment of the tax due through the formal compliance with law without trying to breach it which is known as tax avoidance (TA) practices (Avi-Yonah, 2008).

The firms' involvement in these harmful practices has eroded corporate tax funds which in turn resulted in minimizing tax revenue of the state treasury and therefore the inability of the state to provide public goods and services, and it can be said that the firm's engagement in such practices has a direct impact on society. Therefore, TA practices are not compatible with the concept of CSR (Knuutinen, 2013).

This motivate many scholars to investigate the relationship between CSR engagement and TA practices. Corporate culture, shared value, legitimacy and risk management theories have been used to interpret the association between those two variables. The first one supposes that CSR is part of corporate culture and affects TA behaviors (Kreps, 1990), and the second theory assumes that there is mutual dependence between the company and society and this implies that both corporate business decisions and community policies must follow the principle of shared value and choices must be beneficial to both sides (Porter and Kramer, 2006).

Legitimacy theory (Dowling and Pfeffer, 1975) demonstrates that firm's legitimacy is necessary for its existence and the society has expectations for the appropriate behavior of businesses, and the final theory would consider CSR as risk management tool to avoid any harm to firm's reputation that could be resulted from engaging in negative practices (Fombrun et al., 2000; Moser and Martin, 2012).

According to corporate culture theory, CSR concept will discourage firms to conduct behaviors violating the 'social contract' between firms and individual members of society, like TA practices (Hoi et al., 2013). TA practices are considered as social irresponsible activity because of its negative impact on the economic welfare of the society as stated by shared value theory (Lanis and Richardson, 2015).

From legitimacy perspective, the tax payment is one of the CSR tools to build corporate legitimacy in society and can be considered as an important contribution to community (Preuss, 2010). In contrast with previous mentioned theories, risk management theory indicates that companies may manage CSR activities to protect them from the consequences of aggressive TA activities as they can lead to significant negative consequences for the company (Hoi et al., 2013).

AS theories differ in interpreting the association between CSR engagement and TA practices, the empirical studies disagree about the type of the relationship between those variables. Some studies claim that CSR negatively influences tax avoidance. For example, within American context, Watson (2011) examines the impact of CSR on TA practices through using disclosures about unrecognized tax benefits across a sample of 2294 American companies during the fiscal year 2007/2008. This paper shows that CSR firms have lower unrecognized tax benefits which indicate that CSR firms are less likely to engage in TA practices.

Hoi et al. (2013) also focus on the irresponsible CSR activities to determine the influence of such activities on TA across a sample of 3000 American companies through the period from 2003 to 2009 and they find that companies with excessive irresponsible CSR activities are more aggressive in avoiding taxes sine they have a higher probability of engaging in tax sheltering activities and greater discretionary/permanent book-tax differences. Besides this, Lanis and Ricardson (2015) depend upon a KLD database as a measure of CSR performance for a sample of 434 observations in the USA during the period (2003-2009). They found that the greater the firm's commitment to CSR, the lower the possibility of engaging in TA practices. 
Across a sample of 168 Canadian firms during the period from 2004 to 2008, Landry et al. (2013) examine the relationship between CSR activities and paying the fair share of tax. They found that the socially responsible companies engage less in aggressive TA practices. Zeng (2016) is another study that provides evidence that Canadian CSR firms engage less in TA practices. She examine a sample of Canadian companies listed on SandP/TSX 60 for five years from 2005 to 2009, and she found that the higher the company's ranking in relation to their social responsibility, the lower the probability of the company being involved in aggressive TA practices.

Depending upon Vigeo database, Laguir et al. (2015) investigate whether the relationship between aggressive TA practices and CSR depends upon the nature of CSR activities across a sample of 83 firm-year observations from 24 French listed firms. They concluded that the higher the level of social (environmental) dimension of CSR, the less (more) aggressive the tax practices. In addition, Muller and Kolk (2015) added another dimension to the studies on this issue by comparing local companies to multinational companies through using data of 82 Indian companies during 2000/2001. They found that Indian multinational companies have higher effective tax rate than those of national companies and affiliates of multinational companies that engage more in CSR activities pay more tax than those that don't take care about CSR activities.

In a more recent study, Amidu et al. (2016) examine the relationship between corporate TA and CSR across a sample of non-financial firms listed on the Ghana Stock Exchange (GSE) and non-listed firms from Ghana Revenue Authority (GRA) database during the four-year period from 2010 to 2013. They employ the effective tax rate methodology to measure tax avoidance and three criteria have been used to measure CSR: expert valuation; content analysis of annual reports and other corporate documents and performance in controlling pollution. They indicate that Ghanaian firms with high level of CSR activities engage less in TA practices.

At the opposite side, some scholars conclude that companies that engage in CSR are not paying a substantial higher amount of taxes. Some qualitative studies (e.g., Christensen and Murphy, 2004; Preuss, 2010, 2012; Sikka, 2010) show that firms may appear to be ethically and socially responsible even as they adopt tax aggressive behaviors. Similarly, some empirical studies claim that the relationship between CSR performance and tax avoidance is positive. For example, Huseynov and Klamm (2012) examine the impact of three measures of CSR activities (Corporate Governance, Society and Diversity) on TA practices across a sample of 500 American companies during the period from 2000 to 2008. They also classify each measure of CSR into strengths and weaknesses and tax avoidance was measured by the long-term effective tax rate. They concluded that the weaknesses of the society category of CSR were positively correlated with the effective tax rate, while the strengths of the corporate governance category and the weakness of the diversity category adversely affected the effective tax rate.

Davis et al. (2013) is another study that investigates this relationship within American context. They examine the association between CSR measures and the amount of corporate taxes paid and the amount invested in tax reduction activities for all American public companies during the period from 2002 to 2010. They use data derived from the KLD and Compustat sources and they found that CSR connects negatively with Effective Tax Rate and positively with tax-lobbying expenditures which indicate that CSR firms pay less taxes and engage in more tax lobbying. In addition, Watson (2015) examines the relationship between CSR and acceptable and unacceptable TA practices through examining Effective Tax Rate and unrecognized tax benefits across a sample of American companies during the period from 2000 to 2011. This paper shows that CSR firms have lower Effective Tax Rates and more unrecognized tax benefits in a comparison to other firms which indicates a high level of acceptable and unacceptable TA practices in CSR firms.

Based upon the review and analysis of previous studies, it can be said that those studies have investigated the relationship between CSR and tax avoidance practices based upon different theories and they are applied in different environments as some studies are conducted in developed countries while others were applied in emerging markets. Given the mixed results on the relationship between CSR and tax avoidance, 
this paper examines the Egyptian scenario, especially after the Egyptian Stock Exchange's issuing of the index in March 2010 in the context of its attention to the recent global trends in the indices of financial markets, which began to focus on the criteria of sustainable development, especially with investors' tendency to link financial standards with nontraditional activities standards, such as maintaining good environmental performance and following good corporate governance standards. In addition, the Egyptian government has taken the initiative to provide benefits for community participation. For example, the Tax Law No. 91 of 2005 , adopted by the government in the context of economic reform, has important social dimensions, including the exclusion of donations and subsidies from the tax base, such as donations and subsidies submitted by companies to the Egyptian public associations and institutions as well as what is granted to hospitals subject to governmental supervision and scientific research institutions, not exceeding $10 \%$ of the annual net profit of the donor company.

At the same time, the Egyptian Tax Authority attempts to reduce the negative impact of tax avoidance practices by introducing an amendment to the income tax law No. 91 of 2005 which gives the tax authority the right to reject any harmful tax avoidance and the cancellation of any tax effects as a result of such practice that affects the tax base. The Income Tax Law No. 91 of 2005 was actually amended with the introduction of Article 92 bis in Law No. 53 of 2014, which states:

"When determining the tax burden, the tax effect of the transaction with the main purpose or one of the main purposes is to avoid or delay the tax shall not be considered, and that the transaction might be in the form of a deal or an agreement or a promise or otherwise, be conducted in one or in many stages, and the purpose is to link the tax to the real economic substance of the transaction." Based upon the above discussion, this paper empirically tests the following hypothesis:

H1: There is a negative relationship between Corporate Social Responsibility (CSR) performance and the extent of tax avoidance (TA) in Egypt.

\section{Research Methodology}

\section{Data and Sample}

Accounting data for tax avoidance and control variables is retrieved from companies' financial reports. The study's sample involves all non-financial companies listed on the Egyptian Corporate Responsibility Index (S\&P/EGX ESG Index) for the period from 2007 t0 2016, but the year 2011 wasn't involved as the index wasn't issued in this year. After matching the CSR data with the accounting data, the initial sample is 268 observations. Consistent with prior research, financial firms $(N=80$ firm-years) are excluded as various accounting policies are adopted by those companies, which they would have various factors that impact on the tax avoidance. Additionally, companies that have omitted data are ignored from the study sample ( $N=9$ firm-years), leaving the study's final sample comprising of 179 firm-year observations. All observations distributed by industry and year are shown in Table (1). The table also shows that industrials sector represents the largest industry in the sample (22.9\%), followed by real estate (19\%) and Telecommunications (12.8\%).

Table No. (1) Sample Distribution by Industry and Year

Sample Distribution by Industry:

\begin{tabular}{ccc}
\hline \multirow{2}{*}{ Industry } & \multicolumn{2}{c}{$\begin{array}{c}\text { Complete } \\
\text { Sample }\end{array}$} \\
\cline { 2 - 3 } & $\mathbf{N}$ & $\mathbf{\%}$ \\
\hline Cement & 6 & $3.4 \%$ \\
\hline Chemicals & 22 & $12.3 \%$ \\
\hline Construction & 16 & $8.9 \%$ \\
\hline Consumer Services & 18 & $10.1 \%$ \\
\hline Food \& Beverage & 5 & $2.8 \%$ \\
\hline Healthcare & 1 & $0.6 \%$ \\
\hline Industrials & 41 & $22.9 \%$ \\
\hline Real estate & 34 & $19 \%$ \\
\hline Technology & 13 & $7.2 \%$ \\
\hline Telecommunications & 23 & $12.8 \%$ \\
\hline Total & $\mathbf{1 7 9}$ & $\mathbf{1 0 0 \%}$ \\
\hline
\end{tabular}

Sample Distribution by Year:

\begin{tabular}{ccc}
\hline \multirow{2}{*}{ Year } & \multicolumn{2}{c}{$\begin{array}{c}\text { Complete } \\
\text { Sample }\end{array}$} \\
\cline { 2 - 3 } & N & $\%$ \\
\hline 2007 & 19 & $10.6 \%$ \\
\hline 2008 & 21 & $11.7 \%$ \\
\hline 2009 & 19 & $10.6 \%$ \\
\hline 2010 & 18 & $10.1 \%$ \\
\hline 2012 & 20 & $11.2 \%$ \\
\hline 2013 & 19 & $10.6 \%$ \\
\hline 2014 & 20 & $11.2 \%$ \\
\hline 2015 & 21 & $11.7 \%$ \\
\hline 2016 & 22 & $12.3 \%$ \\
\hline Total & $\mathbf{1 7 9}$ & $\mathbf{1 0 0 \%}$ \\
\hline
\end{tabular}




\section{Variables Measurement}

The research model consists of three variables and here is the way to measure each variable.

\section{1- Independent Variable:}

Corporate Social Responsibility performance (CSR): it is determined by the Egyptian Corporate Responsibility Index (S\&P / EGX ESG Index). This index is created by The Egyptian Institute of Directors (EloD), Egyptian Corporate Responsibility Centre (ECRC) and Standard\& Poor's (S\&P) in March 2010 with the aim of improving the transparency and disclosure practices of Egyptian listed companies with regard to corporate governance and CSR practices, and is the first of its kind to be established in the Middle East (EGX, 2010).

S\&P and the EGX conduct a screening process for all companies listed on the EGX. The screening process incorporates environmental, social and governance (ESG) indicators against which the company's disclosure practices are evaluated. There are two screens, one focusing on environment $\&$ social indicators which are based on output obtained from the mapping of Global Reporting Initiative (GRI), Global Compact (GC) and Millennium Development Goal (MDG) (see Appendix A) and the other one focusing on corporate governance indicators which is an adaption of standard \& Poor's existing corporate governance methodology to suit Egypt's markets (See Appendix B). To arrive at the total score for each of the sampled companies, two scores have to be calculated for each company namely:

a- Quantitative Score - a quantitative ranking is assigned for each of the companies trading on the Egyptian Stock Exchange based on the transparency and disclosure of corporate governance, environmental practices and social practices, and

b- Qualitative Score - a final qualitative score is determined for each company listed on EGX to evaluate the actual performance of the company on a scale of 5 to 1 , with 1 being the lowest and 5 being the highest through using independent sources of information (i.e. news stories, websites and CSR filings).

Finally, the qualitative score and the quantitative score are assembled to calculate a composite score for each company listed on the EGX. Those companies were then ranked according to the composite score and the S\&P/EGXESG Index is constituted from the first 30 companies after reviewing market capitalization and liquidity to ensure that those companies are investable.

\section{2- Dependent Variable:}

Tax avoidance (TA): Effective Tax Rate (ETR) which is the most frequently used measure of tax avoidance is used as a proxy of tax avoidance in this paper.

\section{3- Control Variables:}

In addition to the level of CSR, literature demonstrates firm specific variables that influence the extent of tax avoidance. Therefore, several control variables are included in base regression model which relates to earnings quality, firm performance, and other firm characteristics.

To control for size effects, firm size (SIZE) is included in this study. Based upon Zimmerman (1983), smaller firms are expected to be less tax avoidant than larger firms as smaller firms doesn't enjoy greater economic and political power compared with larger firms and aren't capable of minimizing their tax burdens accordingly. Besides a firm size, a growth variable, sales growth (GROWTH) and a profitability variable, return on assets (ROA) are also included in base regression model along the lines of preceding ETR studies (Gupta \& Newberry, 1997; Adhikari et al., 2006). 
Gupta \& Newberry (1997) stated that a firm's capital structure is empirically linked to ETR as the tax deductibility of debt can be described as the capital structure. Therefore, a firm with a significant debt will be with a poorer extent of ETR and vice versa. Therefore, financial leverage (LEV) is included in this study as a control variable.

Depending upon the paper of Desai \& Dharmapala (2009), total accruals (TAC) is incorporated as a control variable to make sure that the relationship between CSR and tax avoidance is not driven by earnings quality.

Capital intensity (CINT) and inventory intensity (INVINT) are included as a control variable to control for the impact of fixed assets on the level of tax avoidance. It is also argued by Stickney \& McGee (1983) that capital intensive companies should be more tax avoidant than inventory-intensive companies. The measurement of the independent, dependent and control variables of the research will be shown in the following table:

Table No. (2)

Measurement of the Study Variables:

\begin{tabular}{|c|c|}
\hline Variable & Measurement \\
\hline \multicolumn{2}{|r|}{ Independent variable } \\
\hline CSR & The natural log of the firm's ranking in the Egyptian Corporate Responsibility Index (S\&P/EGX ESG Index) \\
\hline \multicolumn{2}{|r|}{ Dependent variable } \\
\hline ETR & ETR is calculated through dividing the total corporate tax expense by net profit before tax. \\
\hline \multicolumn{2}{|r|}{ Control variables } \\
\hline SIZE & Natural log of total asset. \\
\hline GROWTH & Sales growth rate is calculated through the following equation: $\frac{\text { Sales }_{i, t}-\text { Sales }_{i, t-1}}{\text { sales }_{i, t-1}}$ \\
\hline $\mathrm{ROA}$ & Income before extraordinary items / the total assets. \\
\hline LEV & Total debt / total assets. \\
\hline TAC & $\begin{array}{l}\text { It will be measured through the following equation: } \\
\text { TACi,t }=(C A T i, t-C A T i, t-1)-(C L T i, t-C L T i, t-1)-(C S l i, t-C S l i, t-1)+(D C L i, t-D C L i, t-1)-D P A i, t / A T i, t-1 \\
\text { Where: } \\
\text { - CAT = the total current assets of a company. } \\
\text { - CLT = the total current liabilities. } \\
\text { - CSI = cash and short-term investments. } \\
\text { - DCL = the debt in current liabilities. } \\
\text { - DPA = the depreciation and amortization. } \\
\text { - AT = total assets. }\end{array}$ \\
\hline CINT & Property, Plant and Equipment / Total assets. \\
\hline INVINT & Inventory/total assets. \\
\hline
\end{tabular}

\subsection{Empirical Model}

After gathering data, the following regression equation is estimated to test the hypothesis of the research:

$\mathrm{ETR}_{\mathrm{i}, \mathrm{t}}=\alpha 0+\alpha_{1} \operatorname{CSR}_{\mathrm{i}, \mathrm{t}}+\alpha_{2} \operatorname{SIZE}_{\mathrm{i}, \mathrm{t}}+\alpha_{3} \mathrm{GROWTH}_{\mathrm{i}, \mathrm{t}}+\alpha_{4} \mathrm{ROA}_{\mathrm{i}, \mathrm{t}}+\alpha_{5} \operatorname{LEV}_{\mathrm{i}, \mathrm{t}}+\alpha_{6} \operatorname{TAC}_{\mathrm{i}, \mathrm{t}}+\alpha_{7} \mathrm{CINT}_{\mathrm{i}, \mathrm{t}}+\alpha_{8}$ $\mathrm{INVINT}_{\mathrm{i}, \mathrm{t}}+\varepsilon_{\mathrm{i}}$

Where:

- $\quad \mathrm{ETR}_{\mathrm{i}, \mathrm{t}}=$ Total corporate tax expense divided by net profit before tax.

- $\quad \mathrm{CSR}_{\mathrm{it}}=$ The natural log of the firm's ranking in the Egyptian Corporate Responsibility Index (S\&P/ EGX $X^{i, t}$ ESG Index). 
- $\quad \mathrm{SIZE}_{\mathrm{i}, \mathrm{t}}=$ The natural logarithm of total assets.

- GROWTH $_{\mathrm{i}, \mathrm{t}}=$ sales growth.

- $\quad \mathrm{ROA}_{\mathrm{i}, \mathrm{t}}=$ Income before extraordinary item divided by total assets.

- $\quad$ LEV $_{\text {i,t }}=$ Total debt divided by total assets.

- $\quad \mathrm{TAC}_{\mathrm{i}, \mathrm{t}}=$ Total accruals.

- $\quad \mathrm{CINT}_{\mathrm{i}, \mathrm{t}}=$ Total assets divided by total assets.

- $\quad$ INVINT $_{i, t}=$ Inventory divided by total assets.

\section{Empirical Results}

This section is divided into three parts. The first part shows descriptive statistics of study variables while the correlation matrix between study variables is represented in the second part. The last part indicates the results of the data of the association between Corporate Social Responsibility (CSR) and Tax Avoid-

Table No. (3)

Descriptive Statistics ance (TA) in respect of the proposed hypothesis illustrated.

\section{Descriptive Statistics}

Table (3) illustrates descriptive statistics of the complete sample. It is shown in table (3) that CSR ranges between 0 and 3.401197.

\section{The Correlation Matrix}

Table (4) presents Pearson's correlation coefficients for the study variables. As illustrated in the table, CSR is positively correlated with ETR, which suggests that the effective tax rate is higher companies with high tendency to engage in CSR. It is also detected that CSR firms are inventory intensive and with higher earnings quality.

Table No. (4)

Correlation Matrix

\begin{tabular}{|c|c|c|c|c|c|c|c|c|c|}
\hline & ETR1 & CSR & SIZE & ROA & GROWTH & LEV & CINT & INVINT & TAC \\
\hline ETR1 & 1 & & & & & & & & \\
\hline CSR & $0.0967^{*}$ & 1 & & & & & & & \\
\hline SIZE & -0.0093 & -0.077 & 1 & & & & & & \\
\hline ROA & -0.096 & 0.032 & 0.1648 & 1 & & & & & \\
\hline GROWTH & -0.0978 & -0.013 & 0.0414 & 0.0063 & 1 & & & & \\
\hline LEV & -0.0304 & 0.1104 & $-0.218^{* * *}$ & $-0.449 * * *$ & -0.0126 & 1 & & & \\
\hline CINT & 0.0916 & 0.051 & -0.087 & -0.0818 & -0.117 & $0.391^{* * *}$ & 1 & & \\
\hline INVINT & 0.0623 & $0.1847^{*}$ & 0.0001 & -0.0819 & -0.115 & $0.208^{* * *}$ & $0.1337^{*}$ & 1 & \\
\hline TAC & -0.0199 & $-0.152^{*}$ & $0.1275^{*}$ & $0.1528^{* *}$ & -0.0172 & -0.1777 & $-0.126^{*}$ & 0.0229 & 1 \\
\hline
\end{tabular}

Note: $*, * *, * * *$ indicate the significance at the $0.10,0.05$ and 0.01 levels, respectively.

\section{Multivariate Results:}

Table (5) shows the regression results of CSR on ETR1. It is illustrated that the estimated CSR coefficient is positive $(0.138)$ and significant $(p<0.10)$, indicating that the higher the company's ranking in relation to their social responsibility, the higher their ETR1. This result is consistent with prior empirical results documented by Landry et al. (2013), Lanis \& Ricardson (2012, 2015) and Watson (2011, 2015). 
With regard to control variables, the results show that (CINT) loads both negatively and significantly with ETR, which indicates that capital intensive firms are more tax avoidant as argued by Stickney \& McGee (1983).

\section{Robustness Test:}

To examine whether prior results are robust to the alternative measure of accruals quality, the model is re-estimated by replacing ETR1 with the alternative proxy of tax rate as a dependent variable. This measure is based taxes paid on that is introduced by (Dyreng et al., 2008; Minnick \& Noga, 2010):

Cash ETR = Taxes paid in cash / net profit before tax

It is recognized that there is difference between tax expense and taxes paid. For example, tax expense includes deferred or accrued taxes, which are determined according to accounting rules, but may be subject to earnings management (Hanlon \& Heitzman, 2010), whereas cash payments reflect cash outflows. In general, this alternative test supports the same results that are obtained using ETR in table 5. As shown in table 6, it is found that CSR has significantly positive coefficient in this regression of Cash ETR $(0.174, \mathrm{p}<0.1)$; consistent with the hypothesis $\mathrm{H} 1$ that there is a negative relationship between CSR and TA practices.

\section{Conclusions}

This paper examines the connection between Corporate Social Responsibility (CSR) and Tax Avoidance (TA) in the Egyptian context. Specifically, it investigates whether a firm's engagement in ethical activities in Egypt is driven by moral obligation or opportunistic behavior across a sample of 179 firm-year observations for the period between 2007 and 2016. After controlling for firm-specific factors, the empirical findings of this paper show that Egyptian CSR firms are less likely to engage in TA practices.

This study is not without its caveats. It focuses only on the firm's ranking in the Egyptian Corporate Responsibility Index (SandP/EGX ESG Index) and this may not accurately capture the true underlying attributes regarding actual CSR engagement; therefore, this may affect CSR measurement. Despite this limitation, it is believed that this paper's results offer a better comprehension of moral values, and CSR to regulators, setters of the standards, investors and scholars interested in the area of ethical business, by helping them to develop their understanding of business ethics and the integrity of the management related to CSR. In particular, this study provides robust support for the view that a moral imperative motivates firms to engage in CSR activities. Further research could examine this issue by including the impact of different forms of ownership structure, numerous characteristics of executives and governance characteristics on dominating ethical considerations in making decision regarding CSR activities. 


\section{References:}

Adhikari, A.; Derashid, C. and Zhang, H. (2006). "Public policy, political connections, and effective tax rates: longitudinal evidence from Malaysia", Journal of Accounting and Public Policy, Vol. 25, pp. 574-595.

- $\quad$ Amidu, M.; Kwakye, T. O.; Harvey, S. and Yorke, S. M. (2016). "Do firms manage earnings and avoid tax for corporate social responsibility?", Journal of Accounting and Taxation, Vol. 8, No. 2, pp. 11-27.

- $\quad$ Avi-Yonah R.S. (2008) Corporate Social Responsibility and Strategic Tax Behavior. In: Schön W. (eds) Tax and Corporate Governance. MPI Studies on Intellectual Property, Competition and Tax Law, vol 3. Springer, Berlin, Heidelberg. https://doi.org/10.1007/978-3-540-77276-7_13

- $\quad$ Borza, A. and Stoian, C. D. (2011). “Managing corporate aocial responcibility actions through tax avoidance practices". Managerial Challenges of the Contemporary Society. Vol. 2, pp. 296-299. Christensen, J. and Murphy, R. (2004). “The social irresponsibility of corporate tax avoidance: Taking CSR to the bottom line", Development, Vol. 47, No. 3, pp. 37-44.

- Davis, A.; D. Guenther, L. Krull and B. Williams. (2013). Taxes and corporate accountability report-ing: Is paying taxes viewed as socially responsible?. Working paper, University of Oregon.

- Desai, M. and Dharmapala, D.(2009). "Corporate tax avoidance and firm value", The Review of Economics and Statistics, Vol. 91, pp. 537-546.

- Dowling, J. and Pfeffer, J. (1975). “Organizational Legitimacy: Social Values and Organizational Behaviour", Pacific Sociological Review, Vol. 18, pp. 122-136.

- Dyreng, S. D.; Hanlon, M. and Maydew, E. L. (2008). "Long-run corporate tax avoidance", The Accounting Review, Vol. 83, No.1, pp. 61-82.

- Egyptian Center for Corporate Responsibility. (2016). The Egyptian Index of Corporate Responsibility, available online at: http://www.ecrc.org.eg/ESGIndex.aspx.

- Egyptian law of income tax number 53 for the year .(2014). available online at: http://www.incometax.gov.eg/pdf/law-53-2014.pdf

- Egyptian law of income tax number 91 for the year (2005). available online at: http://www.incometax.gov.eg/pdf/new-law.pdf.

- $\quad$ Fombrun, C. J.; Gardberg, N. A. and Barnett, M. L. (2000), “Opportunity platforms and safety nets: Corporate citizenship and reputational risk", Business and Society Review, Vol. 105, No.1, pp. 85-106.

- Gupta, S. and Newberry, K. (1997). "Determinants of the variability in corporate effective tax rates: Evidence from longitudinal data", Journal of Accounting and Public Policy, Vol.16, No. 1, pp.1-34. Hanlon, M. and Heitzman, S. (2010). "A review of tax research", Journal of Accounting and Economics, Vol. 50, No. 2, pp. 127-178.

Hasseldine, J. and Morris, G. (2013). “Corporate social responsibility and tax avoidance: A comment and reflection", Accounting Forum, Vol. 37, No. 1, pp. 1-14.

- Hoi, C.K.; Wu, Q. and Zhang, H. (2013). "Is corporate social responsibility (CSR) associated with tax avoidance? Evidence from irresponsible CSR activities", The Accounting Review, Vol. 88, No. 6, pp. 2025-2059.

- Huseynov, F. and Klamm, B. K. (2012). “Tax avoidance, tax management and corporate social responsibility", Journal of Corporate Finance, Vol. 18, No. 4, pp. 804-827.

- Jones, T. M. (1995). "Instrumental stakeholder theory: A synthesis of ethics and economics", AcademyofManagement Review, Vol. 20, No. 2, pp. 404-437.

Khan, M.; Yousaf, Z.; Khan, Z. A. and Yasir, M. (2014). "Analysis of the relationship between CSR and tax avoidance: An evidence from Pakistan", The International Journal of Business and Management, Vol. 2, No. 7, pp. 53-57. 
Knuutinen, R. (2013). “International tax planning, tax avoidance and corporate Social responsibility", Interdisciplinary Studies Journal, Vol. 3, No. 1, pp. 73-84.

- Kreps, D. M. (1990). "Corporate culture and economic theory", In: Perspectives on Positive Political Economy, edited by J. E. Alt and K. A. Shepsle. Cambridge, U.K.: Cambridge University Press.

- Laguir, I.; Staglianò, R. and Elbaz, J. (2015). “Does corporate social responsibility affect corporate tax aggressiveness?", Journal of Cleaner Production, Vol. 107, pp. 662-675.

- Landolf, U. (2006). "Tax and corporate responsibility", International Tax Review, Vol. 29, pp. 6-9.

- Landry, S.; Deslandes, M. and Fortin, A. (2013). “Tax aggressiveness, corporate social responsibility, and ownership structure", Journal of Accounting, Ethics and Public Policy, Vol. 14, pp. 611-645. Lanis, R. and Richardson, G. (2012). "Corporate social responsibility and tax aggressiveness: An empirical analysis", Journal of Accounting and Public Policy, Vol. 31, No. 1, pp. 86-108.

- Lanis, R. and Richardson, G. (2015). "Is corporate social responsibility performance associated with tax avoidance?", Journal of Business Ethics, Vol. 127, No. 2, pp. 439-457.

- Minnick, K. and Noga, T. (2010). “Do corporate governance characteristics influence tax management?", Journal of Corporate Finance, Vol. 16, No. 5, pp. 703-718.

- Moser, D. V. and Martin, P. R. (2012). "A Broader Perspective on Corporate Social Responsibility: Research in Accounting", The Accounting Review, Vol. 87, No. 3, pp. 797-806.

- Muller, A. and Kolk, A. (2015). "Responsible tax as corporate social responsibility: the case of multinational enterprises and effective tax in India", Business and Society, Vol. 54, No. 4, pp. 435-463. Ostas, D. T. (2004). “Cooperate, comply, or evade? A corporate executive's social responsibilities with regard to law", American Business Law Journal, Vol. 41, No. 4, pp. 559-594.

Porter, M. E. \& Kramer, M. R. (2006). “The link between competitive advantage and corporate social responsibility", Harvard Business Review, Vol. 84, No. 12, pp. 78-92.

- Preuss, L. (2010). "Tax avoidance and corporate social responsibility: you can't do both, or can you?", Corporate Governance, Vol. 10, No. 4, pp. 365-374.

- Preuss, L. (2012). "Responsibility in paradise? The adoption of CSR tools by companies domiciled in tax havens", Journal of Business Ethics, Vol. 110, No. 1, pp. 1-14.

- Rose, J. M. (2007). “Corporate directors and social responsibility: Ethics versus shareholder value". Journal of Business Ethics, Vol. 73, No. 3, pp. 319-331.

- Sikka, P. (2010). "Smoke and mirrors: corporate social responsibility and tax avoidance", Accounting Forum, Vol. 34, pp. 153-168.

Stickney, C. and McGee, V. (1983). "Effective corporate tax rates the effect of size, capital intensity, leverage, and other factors", Journal of Accounting and Public Policy, Vol. 1, pp. 125-152.

Watson, L. (2011). Corporate social responsibility and tax aggressiveness: An examination of unrecognized tax benefits. The Pennsylvania State University working paper.

- Watson, L. (2015). “Corporate social responsibility, tax avoidance and earnings performance”, The Journal of the American Taxation Association, Vol. 37, No. 2, pp. 1-21.

- Williams, D. F. (2007). Tax and Corporate Social Responsibility. KPMG, London.

- Zeng, T. (2016). “Corporate social responsibility, Tax aggressiveness and firm market value", Accounting Perspectives, Vol. 15, No. 1,pp. 7-30.

Zimmerman, J. (1983). "Taxes and firm size", Journal of Accounting and Economics, Vol. 5, No. 2, pp. 119-149. 


\section{Appendix}

Appendix A: Tand D Template for Assessing Environment and Social conduct (E and S) of Egyptian Companies:

\begin{tabular}{cl}
\hline Environment & Environmental Pollution \\
& Natural Resources Use \\
& Management Policy and Performance Indicators \\
\hline \multirow{2}{*}{ Employees } & Employee Relations/Job Creation \\
& Labor Rights \\
& Equal Opportunity \\
& Union Relations \\
\hline \multirow{2}{*}{ Community } & Human Rights \\
& Community Investment \\
\hline \multirow{2}{*}{ Customers/ Product } & Product Safety \\
& $\begin{array}{l}\text { Anti-trust } \\
\text { Customer Outreach and product Quality }\end{array}$ \\
\hline
\end{tabular}

\section{Appendix B: Tand D Template for Assessing Conduct on Governance of Egyptian Companies:}

\begin{tabular}{cl}
\hline Ownership Structure and Shareholder Rights & $\begin{array}{l}\text { Shareholder Capital } \\
\text { Shareholder Rights }\end{array}$ \\
\hline Financial and Operational Information & $\begin{array}{l}\text { Financial Information } \\
\text { Operational Information }\end{array}$ \\
\hline Board and Management Structure and Process & $\begin{array}{l}\text { Board and Management Information } \\
\text { Board and Management Remuneration }\end{array}$ \\
\hline \multirow{2}{*}{ Business Ethics and Corporate Responsibility } & $\begin{array}{l}\text { Corporate Governance } \\
\text { Corruption } \\
\text { Leadership } \\
\text { Business Ethics }\end{array}$ \\
\hline
\end{tabular}

